\title{
Slow-Walk: Climate as Volatility and Expansive Political Practice
}

May Joseph

\author{
"A lot of restless water" \\ Randy Martin, Knowledge LTD
}

A

lone tree stands in the midst of a devastated landscape at Rikuzentakata, Japan. At Aceh, Malacca, a whole generation is washed out by the 2004 tsunami. At Beach 116, Far Rockaway, New York City, the entire street is swept away as the sea rolls in from the ocean toward the Jamaica Bay end of the avenue, built on a slope from ocean to bay on a barrier island. These scenes of climate volatility arouse in coastal communities a sense of vulnerability, of risk as a way of life. It is a daily choreography of uncertainty whose underlying structures shape the performance work of the movement-based theater company Harmattan Theater, which I started in 2009.

I founded Harmattan Theater in 2009 as a response to the issues of rising ocean waters. The tsunami of 2004 clarified the goals of Harmattan's mission: to engage with coastal communities and vulnerable waterfronts around the world through site-specific community work. Trained in Bharatanatyam, Vipasana, Kalaripayattipayyatu, and Kyogen movement techniques, I applied notions of slow-walking from different movement traditions to create an aesthetic of walking through endangered landscapes. Retracing buried water sources, reclaiming waterfronts destroyed by storm surge, these are some of the themes that propel my work through movement. Performance is a powerful tool to engage with climate adaptation. Creating a shared vernacular of slow-walk with local residents allows an ecological understanding of disappearing shorelines to emerge across cultures. I felt a need to do this as my own family had experienced the long tentacles of the 2004 tsunami in Alleppey, India, where a hundred people had died as the surge washed away the ancient fishing village's shoreline. The 2004 tsunami metaphorically raises many questions about probability, about futurity, about ecology, and about response to risk. A movement-based vehicle that can respond to the diabolical unpredictability of tsunamis, storms, and rising seas along precarious archipelago sites seemed to me a sustainable response to the impending crisis at hand: monster waves, punishing hurricanes.

The sea is a shared fate. How we respond to volatilities elsewhere shapes our own preparedness for the unexpected arrivals of storm surges on our shores. Movement, dance, ritual, trance performance, and the vipasana technique of the slow-walk are powerful movement techniques to engage

May Joseph (harmattantheatercompany@gmail.com) is professor of social science at Pratt Institute. She is founder of the environmental theater company, Harmattan Theater, and author of Fluid New York and Nomadic Identities. Joseph works with coastal communities creating site-specific performances dealing with water politics around the world. 
with the eroded shorelines of past storms, the decaying sea walls of former colonial empires. The slow-walk is the focal point of the choreography of risk in my experiments with storm surge landscapes. Slow-walk is a practice of quotidian engagement. It is a praxis of unlearning landscape. Slowing the pace down, expanding temporality, forces the individual to focus on the details of an otherwise neglected landscape. Walking imperceptibly, gliding along the edges of waterscapes, opens up a fluidity of movement. People find their gait slowing down as the rhythm of the sea redefines pace. Slow-walking allows coastal communities to immerse themselves in their water-bound landscapes. Harmattan's technique of the slow-walk is distinct from the German Wanderung or Baudelaireian flânerie in that the walk is a slowing down of time. It is closer to Eadweard Muybridge's freeze frame, stop motion process, where the participants/performers immerse themselves in each movement, engage with every phase of the gait, absorbing landscape through the walk. Walking along the waterline morphs coastal dwellers into concerned citizens. It is an imperceptible transformation that becomes social, as Martin's idea of a social kinesthetic takes hold of the performance. Bringing people to their shorelines in a gradual meander forces individuals to decelerate and take a stroll through a scenario they have stopped noticing and ceased thinking about. Walking mindfully opens up the spaces of risk. It expands the spaces of volatility, of probability.

It is one of those glorious, sunny August days in New York City when you can smell the garbage in the very air. It is the year 2000. Buildings haven't fallen down in Manhattan, and hurricanes haven't redesigned New York yet. I am sitting on the yellowing stairs of the Carrara-marbled, Tiffany-windowed venerable Pratt Library with Randy Martin. I am the new cultural studies hire in his department at Pratt. We talk about how I can incorporate performance practice into a cultural studies ethos. "This is the place to do it," Martin encourages. Conjoining social theory and corporeality was central to Martin's own methodology. It was rooted in a theory of praxis as political engagement, which Martin grounded in institutional place making.

Martin's creation of the graduate program in art policy at New York University is one instance of his administrative genius in merging theory with institutional possibility. Prior to this, Martin had initiated the undergraduate bachelor's degree program in cultural studies at Pratt Institute with an innovative eye toward grafting the applied arts to a materialist investigation of social theory. Modeling the program after the British polytechnic and art school ethos that had grounded the early experiments in cultural studies methodologies in Britain, Martin's cultural studies program at Pratt Institute was both visionary and a failed idea. It was far-sighted in so far as it was one of the few places in the United States where an undergraduate education in both art practice and cultural materiality could be harnessed toward a liberal arts degree. It was a failed idea because the category of "cultural studies" was never a marketable idea at the undergraduate level, for college recruiters in the United States. At Pratt, the singular lament from the marketing division of the institute was "we do not know how to market the Cultural Studies program"1 to prospective undergraduates. The program became a living instance of both the promises of a cultural studies approach to the study of culture in the United States, as Martin had set out to establish at Pratt, and of the institutional limits of marketability that hounded interdisciplinary programs such as Pratt's Cultural Studies undergraduate degree. Recruiters simply didn't "get" what cultural studies is. Girding the troubled undergraduate major was the political ethos of artistic praxis as engagement with the world. This structuring idea of praxis as the "expansive capacity" (Martin 2015) in politics, to use Martin's phrase, has endured as a pedagogical ethos in the Department of Social Science and Cultural Studies at Pratt Institute, which Martin re-ignited and transformed from a languishing social science casualty into a dynamic interdisciplinary department.

The case of Pratt is exactly the sort of risk taking that Martin's embrace of an expansive political praxis entails. As a protégé of the sociologist Stanley Aronowitz, Martin's own immersion in social movement theory informed his administrative decision-making practices. Creating conjunctures with limited resources and forcing a more emancipatory articulation of the financialization of academia - this is what Martin created at Pratt at a time of great institutional impoverishment.

s




\section{Note}

1. From 2003-2005, I served as director of the cultural studies undergraduate degree major that Randy Martin had founded at Pratt. Much of my tenure was spent battling Pratt administration to put resources into marketing cultural studies, which the administration persistently argued was unmarketable. Martin's departure from Pratt Institute in 2000 for New York University left an administrative vacuum. Bereft of the stewardship of Martin as chair of the department, the cultural studies project at Pratt eventually transitioned from a major to a minor. However, his pedagogical and Marxist commitments left deep and influential legacies in the curriculum of Pratt Institute's social science department.

\section{Work Cited}

Martin, Randy. 2015. Knowledge LTD.: Toward a Social Logic of the Derivative. Philadelphia: Temple University Press. 